\title{
Tenun Sasak in Indonesian Legal Discourse: from Cultural Heritage to Local Economic Booster
}

\author{
Dwi Martini", Budi Sutrisno**, Kurniawan ${ }^{* * *}$ \\ DOI: https://doi.org/10.22304/pjih.v6n3.a8 \\ Submitted: July 31, 2019 | Accepted: December 27, 2019
}

\begin{abstract}
The Tenun Sasak, an Indonesian traditional woven fabric, requires proper legal protection to prevent and to solve various violations of laws. Currently, there is no single sui-generis law on the subject matter as it sporadically regulated in several laws. This article examines issues related to the perspective of Sasak community toward Tenun Sasak, existing regulation on economic and cultural aspects of Tenun Sasak in Indonesian legal discourse, and the expected legal protection form to preserve its economic and cultural values. To address these issues, the study applied socio-legal research methodology by combining primary legal material, literatures, and secondary legal material to gain clearer de jure and de facto perspective. For Sasak community, the traditional woven fabric is not only body cover. It contains more depth values such as inter-generation cultural inheritance, reflection of socio-cultural values, and source of livelihood. In Indonesian legal discourse, Tenun Sasak is regulated in certain laws and regulations ranging from Intellectual property (IP) and others. The expected forms of laws to protect the economic and cultural values consist of establishment of database, sui generis law, and local law on the subject matter. It can be concluded that to protect and preserve the economic and cultural dimension of the subject matter, a holistic legal arrangement is required both inside and outside the IP system.
\end{abstract}

Keywords: Economic, Legal, Tenun

\section{Tenun Sasak dalam Diskursus Hukum Indonesia: dari Warisan Budaya Hingga Pendorong Ekonomi Lokal}

\begin{abstract}
Abstrak
Kain tenun tradisional merupakan aset nasional Indonesia yang tidak saja bernilai budaya tapi juga bernilai ekonomi tinggi. Eksistensi kain tenun, khususnya kain tenun Sasak, membutuhkan perlindungan hukum yang memadai untuk mencegah dan menindak berbagai bentuk pelanggaran terhadap pemanfaatan kain tenun Sasak yang merugikan kepentingan Negara. Pada saat ini perlindungan tersebut telah diatur dalam beberapa
\end{abstract}

PADJADJARAN Journal of Law Volume 6 Number 3 Year 2019 [ISSN 2460-1543] [e-ISSN 2442-9325]

* Lecturer of the Faculty of Law, Mataram University, JI. Majapahit No. 62, Mataram, SH [Universitas Mataram], MH [Universitas Mataram], e-mail: dwimaret@unram.ac.id

** Lecturer of the Faculty of Law, Mataram University, Jl. Majapahit No. 62, Mataram, SH [Universitas Gadjahmada], MH [Universitas Diponegoro], e-mail: soetrisnoboedhi@yahoo.com.

*** Lecturer of the Faculty of Law, Mataram University, J. Majapahit No. 62, Mataram, SH [Universitas Mataram], MH [Universitas Pasundan], Dr [Universitas Pasundan], email: kurniawan_fhunram@yahoo.com. 
undang-undang secara parsial, karenanya masalah seputar pandangan masyarakat Sasak terhadap kain tenun Sasak, pengaturan aspek ekonomi dan budaya kain tenun Sasak dalam diskursus hukum Indonesia dan bentuk perlindungan yang memadai untuk melindungi aspek ekonomi dan budaya pada kain tenun Sasak dielaborasi dalam artikel ini. Untuk menjawab masalah diatas, digunakan metode penelitian hukum normatif-empiris yang memadukan bahan hukum primer berupa kepustakaan dengan bahan hukum sekunder berupa wawancara dengan para narasumber yang berkaitan dengan objek penelitian. Bagi masyarakat adat Sasak, kain tenun tidak saja sebatas kain penutup melainkan mempunyai beberapa nilai yang jauh lebih mendalam yaitu: sebagai warisan yang diturunkan antar generasi, refleksi nilai sosial dan budaya serta sumber mata pencaharian dalam diskursus hukum Indonesia kain tenun diatur dalam beberapa undang-undang yaitu Undang-Undang di bidang Kekayaan Intelektual dan Undang-Undang di luar bidang Kekayaan Intelektual. Bentuk ketentuan hukum yang diharapkan untuk melindungi aspek ekonomi dan budaya kain Tenun Sasak berupa: pembentukan database, Undang-Undang Sui Generis dan Pembentukan Peraturan Daerah tentang Kain tenun. Pembentukan peraturan di atas beserta sosialisasi yang lebih intensif kepada masyarakat adat, pegiat IKM maupun pemerhati kain tenun diperlukan untuk meningkatkan kesadaran akan eksistensi dan muatan ekonomi maupun budaya yang terkandung di dalam kain Tenun Sasak.

Kata kunci: Ekonomi, Hukum, Tenun

\section{A. Introduction}

Weaving has become an integrated activity of local indigenous people of Indonesia, including Sasak community. The Sasaks are the native residents of Lombok Island, West Nusa Tenggara Province. They call the weaving activity nyensek or nyesek. It aims to produce woven fabric. Usually, to fulfill basic cloth needs, the Sasak women performed the activity. In the perspective of Sasak community, weaving is a mandatory skill for women that can be useful in marriage life. Currently, Traditional Weaving Fabric (TWF) has transformed into a valuable commodity, due to the increase of public's interest on cultural products. It becomes a part of modern lifestyle. It is proven by a high demand of tourism and garment sectors leading the fabric to be a luxurious souvenir or expensive ready, which in turn positively influence local's economy.

Historically, weaving is conceived from a constant interaction between culture, art, and technique that are reflected in various methods and fabric's patterns. According to the character, Tenun Sasak can be categorized as "traditional cultural expression" (TCE). In other words, it is a form of intangible asset that contains socio-cultural and socio-economic value ${ }^{1}$ that needs to be protected and conserved appropriately.

Therefore, the state has the obligation to ensure that the subject matter earns proper recognition, protection, and legal treatment in order to maintain it as a substantial component of people's welfare. Based on the background, this study

Christoph Antons, "Asian Borderlands and the Legal Protection of Traditional Knowledge and Traditional Cutural Expressions", Cambridge Law Journal, Vol. 47, No. 4, 2013, p. 1403. 
examined and elaborated several relevant issues. They are, among others, (1) the perspective of sasak community toward the existence and ownership of traditional weaving fabric in term of economic and culture; (2) legal protection form on the subject matter in Indonesia's legal discourse; (3) the expected protection form, which accommodate Sasak community's economic and cultural interest on the subject matter.

The examination employed qualitative method that was supported by sociolegal method. It applied statutes, conceptual, and comparative approach. This study analyzes the law not only as a set of regulation but also as the interaction of related norms with society in empirical context. The research conducted in the island of Lombok due to the sustainable existence of weaving fabric both culturally and economically in the Sasak people's life.

\section{B. Introduction to Traditional Cultural Expression}

The term Traditional Cultural Expression (TCE) is used initially in the draft of the Law on Traditional Knowledge and Traditional Cultural Expression (RUU-PTEBT) as a replacement of the term folklore, which was used in the Law Number 19 of 2012 on Copyright. The TCE refers to "every form of expression whether material (tangible) and non-material (intangible) or combination of both that indicates the existence of a cultural and traditional expression transmitted from generation to generation". Since the Copyright Law has been amended by the Law Number 28 of 2014, the term TCE is expanded to cover also textual, verbal, music, motion, theatre, fine arts, and traditional ceremonies expressions. In short, the TCE is a part of a community's identity that reflects the people's particular value in aspects of life. To emphasize, the TCE is a part of its community's identity that reflects their particular value and character expressed in fables, ritual, and arts.

On the other hand, the World Intellectual Property Organization (WIPO) describes traditional property as "tradition-based literary, artistic, scientific work, performances, inventions, scientific discoveries, designs, marks, names and symbols, undisclosed information and all other tradition-based innovations and creation". ${ }^{2}$ Thus, TCE covers every forms of expressions, including phonetic or verbal, sound or music expressions, movement or act, and material expressions. It simply is a part of traditional knowledge system specifically related to cultural matters.

From the description above, it can be concluded that there are certain characters of TCE that makes it different from general art expressions. ${ }^{3}$ They are:

1. transmitted orally;

2. traditionally characterized since it developed through some generations;

Sarah S. Kuahaty, "Kain Tenun sebagai Pengetahuan Tradisional Masyarakat Hukum Adat Maluku", http://fhukum.unpatti.ac.id/.../272-kain-tenun-, downloaded on December 10, 2018.

3 James Dananjaya dalam Simona Bustani, "Urgensi Pengaturan Ekspresi Budaya (Folklore) Masyarakat Adat", Jurnal Hukum Prioris, Vol. 2, No. 4, 2010, p. 3. 
3. shaped in self-owned pattern;

4. anonymously;

5. utilized collectively in an indigenous community;

6. pre-logically characterized means that it has its own logic that is may differ from common sense logic; and

7. owned collectively by the entire community.

Nevertheless, "communal ownership" and "traditional" are TCE's prominent characters. Communal ownership, in this discussion, means that all community members own TCE collectively as their life system support. On the other hand, "traditional" character refer to ancestor's heritage or religious tradition that is believed to be earned from God and reflected in the community's language, behavior, norms, principles, ethics, as well as social and lifestyle. ${ }^{4}$ Further, according to Sardjono ${ }^{5}$, the term "traditional" is not identic to old-fashioned and ancient substance. Indeed, it leads to innovation that constantly developed, discovered unsystematically, and linked to values of the community as a response towards the changes of environment. Hence, traditional value of TCE should be the basic of development policy, which involves the community in every aspects of policy making to assign the indigenous people as the main subject of the development. ${ }^{6}$

\section{Philosophical Foundation of Legal Protection and Tradition Cultural Expression in Indonesia}

Indonesia is a pluralistic country that consists of various tribes, tradition, and cultural diversities. Therefore, it has a rich TCE forms resulting from consistent interaction between men, nature, and tradition. Philosophically, legal protection of TCE includes efforts to secure one's interest by providing certain authority to act based on the above interest. ${ }^{7}$ The legal protection ideally must be able to provide law basic values namely certainty, utility, and legal justice.

The foundation of the TCE's protection in Indonesia is the 1945 Constitution that ensures the accomplishment of economic and cultural rights of all citizens to reach social justice. Particularly, the discussion is related to the existence of the indigenous people as the holder and conserver of traditional culture as mandated by Article 18B, Paragraph (2), of the 1945 Constitution as follow.

"The State shall recognize and respect, to be regulated by law, the homogeneity of societies with customary law along with their traditional rights for as long as they remain in existence and in

\footnotetext{
A. Mangunhardjana, Isme Isme dalam Etika dari A-Z, Yogyakarta: Kanisius, 1997, pp. 220-223.

Agus Sardjono, Hak Kekayaan Intelektual dan Pengetahuan Tradisional, Bandung: Alumni, 2006, p. 99.

Dutfield Graham, "Harnessing Traditional Knowledge and Genetic Resources for Local Development and Trade", Draft paper Presented at the International Seminar on Intellectual Property and Development, 2005, p. 6.

7 Satjipto Rahardjo, Sisi Lain Orang Indonesia Jawa, Jakarta: Kompas, 2003, p. 121.
} 
agreement with societal development and with the principle of the Unitary State of the Republic of Indonesia."

The article emphasizes the importance of state's intervention to protect the rights of the indigenous people on every form of cultural products. This view is in line with Locke's natural law theory that ownership is one of the three things that cannot be separated from mankind as human is born free and equal. ${ }^{8}$ In the context of Intellectual Property, it was further break down into reward theory and public benefit theory. According to reward theory, creative individuals shall be benefitted economically from the use of goods produced from the idea. On the other hand, the public benefit theory describes that the basic rationale on Intellectual Property rights granting is economic development. ${ }^{9}$ Therefore, state's acknowledgement and protection is implemented in the form of policies that arrange the ownership, preservation, and utilization of cultural product, especially traditional woven fabric. It is basically meant to distribute welfare to all people of Indonesia.

\section{Economic and Cultural Aspects of Weaving Tradition}

Weaving is a legacy containing cultural and economic dimensions. As a cultural heritage, it is knowledge and wisdom that is taught hereditary. It is strongly linked to the people's character. The pattern, technique, production, and origins of a woven fabric generally contain spiritual, philosophical, and even political value ${ }^{10}$ as follows.

1. The spiritual value: reflection of its holder community's belief system. It is usually appeared in certain fabric pattern that symbolizes faith or its specific usage in particular religious' ritual. Subahnale ${ }^{11}$ pattern, for instance, is adaptation of Sasak dialect for the Arabic-Islamic expression "Subhanalloh", which means "Glory be to God".

2. Philosophical value: creation of traditional fabric containing philosophical and historical background of its society. As an example, Ulos, for the people of Batak owns substantial position to unite people. According to local proverb, "ijuk pangihot ni hodong, ulos pangihot ni holong" whch means that ijuk (coconut fiber) is bonder of midrib to its stem and Ulos is bonder of love among people. ${ }^{12}$

\footnotetext{
8 Yoga Mahardhita and Ahmad Yakub Sukro, "Perlindungan Hukum Hak Kekayaan Intelektual Melalui Mekanisme Cross Border Measures", Jurnal QISTIE, Vol. 11, No. 1, 2018, p. 92.

9 Cholis Roisah, "Kebijakan Hukum "Transferability" Terhadap Hak Kekayaan Intelektual Indonesia”, Jurnal Law Reform, Vol. 11, No. 2, 2015, pp. 245-246.

10 Maria Nona Elvida, "Pembuatan Kain Tenun Ikat Maumere di Desa Wololora, Kecamatan Lela, Kabupaten Sikka Propinsi Nusa Tenggara Timur", Jurnal Holistik, Tahun VIII, No. 16, 2015, p. 4.

11 Hastira Soekardi, "Kenali 3 Jenis Kain Tradisional Suku Sasak Lombok", kompasiana.com/hastira/kenali-3-jenis -kain-tradisional-suku-sasak-lombok_5772d359af7e61870d98500b, downloaded on May 28, 2017

12 Janner Raja Simamarta, “Ulos Batak: Sejarah, Makna dan Jenisnya, Simarmata.or.id/2016/04/ulos-bataksejarah-makna-dan-jenisnya/", downloaded on May 28, 2017.
} 
3. Political value: certain pattern or color can be related to someone's position or power in the community's hierarchy such as chief, elder, or religious leader. Morning star pattern in maumere's woven cloth means light giver, guidance, and disaster deterrent, which can only be wore by leaders of the community. ${ }^{13}$ In economic perspective, esthetic technic or peculiarity aspects in weaving tradition is proven to have highly commercial value, which can drive the increase of several sectors such as tourism and trade.

\section{E. The Perspective of the Sasak People on the Existence and Ownership of Tenun as Economic and Cultural Asset}

Philosophically, cloth or Mawastre is viewed as cover or kampuh for the user's body. ${ }^{14}$ The cloth is not only considered as dress that stick on the body but also part of the user's identity. Hence, cloth is widely used in various occasion and situation, from head cover (sapuq) to baby carrier (umbaq), from wedding ceremony to funeral ritual.

In line with the advances of trade era, the values contained in Tenun Sasak is also transformed. Tenun was used to be made and utilized domestically but now it has become a highly financial-valued commodity. The promising selling price of Tenun becomes the main motivation to introduce the cloth to other society or even to other countries. Art shops and galleries begin to appear in traditional villages across Lombok in order to boost marketing of the cloth. Therefore, the existence of woven cloth contains multi-dimension values. Sasak community perspective towards Tenun can be seen in the cultural and economic functions. The next part is the description if the roles and functions.

\section{Hereditary Legacy}

Traditional weaving is a domestic activity, mostly conducted by women. In some traditional villages, such as Sukarara village in central Lombok, it is a mandatory skill that must be mastered by every girl. Therefore, it is taught to girls from a very young age, around 7 to 10 years old.

$\mathrm{Nacih}^{15}$, one of senior weaver in Sukarara village, confirms the statement. She mentions that she learned the skill from her mother. Initially, she was just asked to watch the activity. She was further learned about weaving tools and materials before joined the activity under her mother supervision. There is an unwritten rule that regulate women who has mastered weaving skill to transfer her skill to other female member of the family. Prior to her marriage, an adult woman must be able to provider clothes for at least herself, her husband, and her mother in law.

Nevertheless, the skill of traditional weaving is owned as a hereditary treasure. Hereditarily does not refer to personal ownership right but also as communal

\footnotetext{
Maria Nona Elvida, op.cit, p. 4.

Yudhi Setiawan, Activist of Paguyuban Rasne Jati, Central Lombok, interviewed in August 2018.

Jero Nacih, one of the weavers in Dusun Ketangga, Desa Terara, Central Lombok regency, interviewed on

September 5, 2018
} 
ownership. For the people of Sasak, as well as other traditional community in Indonesia, there is an assumption that each individual is an integrated part of society. ${ }^{16}$ Thus, traditional weaving skill can be considered as a symbol of intergeneration acknowledgement and understanding that they are a unity and, therefore, bond with similar culture. Such system enables an effective preservation. It is evidence that, within the least government intervention (i.e. socialization and coaching), traditional weaving can still survive as a sustainable tradition. Moreover, up to 2018 , more than three thousand people were known as productive weaver in Sukarara village. ${ }^{17}$

\section{Reflection of Spiritual and Social Values}

Basically, Sasak cultural system is rely on religious taught, Islamic values. There is a principle "adat bertatah agame"18 or tradition is based on the religion. It leads to two main points. First, Islam is the basic guidance of the community's life. Second, the patterns of relationship are constructed in communal, instead of individual, spirit. Both points reflected in various patterns, colors, processes, and functions of the cloth.

Currently more than fifteen traditional and contemporary woven patterns have been invented. Each pattern reflects spiritual and social values living and growing within the society. The Subahnale pattern, for instance, is considered as the most sacred pattern since it requires particular preparation before and during the weaving activities. According to Supardi ${ }^{19}$, in the past, prior to the making of this pattern on a fabric, a weaver must prepare linen net to cover the weaving spot and a bowl of water close to the weaver to prevent mystical "disturbance" from outside. The relation between human and God is symbolized with circular and colorful pattern weaved on the fabric.

Another example is Kembang komak and Ragi Genep patterns, which reflect social-economic value. Kembang komak literally means green peas seed. It symbolizes the community's food staple that grows by farmers other than rice and corn. This pattern displays straight line across the fabric, which is consists of two colors: black and white or green and white. The Ragi Genep pattern symbolizes the joy of harvesting season. Therefore, it can be weaved in multiple colors, or "genep" in Sasak dialect. ${ }^{20}$ In addition, weaving skill can also be a tool of social acceptance as in some indigenous villages, including Sukarara. A woman who came from outside of the society (and coming there due to a marriage) can only be accepted

\footnotetext{
Simona Bustani, op.cit., p. 249.

M. Isnan Abdillah, Head of Governance Matter, Sukarara Village Office, interviewed in September 2018.

See Dwi Martini, et.al, "Legal Protection on Traditional Medicine Knowledge in Indonesia's Intellectual Property Rights (IPR) System (a study in Sasak Traditional community", Jurnal Hukum dan Peradilan, Vol. 6, No. 1, 2017, p. 74.

19 Supardi, Chief of Dusun Ketangga, one of the Dusun in Sukarara Village, Central Lombok regency, interviewed in September 2018.
}

20 Ibid. 
once she masters weaving skill. In other words, weaving plays a role as a social condition within the Sasak people.

\section{Source of Livelihood}

The development of tourism sector in the West Nusa Tenggara Province, especially in the Lombok Island contributes to the economic value of Sasak traditional fabric. Previously, weaving is conducted as a spare time activity other than domestic activities. The garment was made to fulfill domestic need. Since tourist visits constantly increase followed by the increase of people's interest on local and traditional product, weaving becomes main activities to earn living in many villages across Lombok, such as Sukarara and Sade in Central Lombok Regency and Bayan in North Lombok regency. ${ }^{21}$

In order to maintain its economic value, some policies are taken. One of them is the appointment of Sukarara as a cultural tourism destination. The Local Government of Central Lombok has designed and implemented promotion strategy as well as infrastructure enhancement such as transportation and accommodation to enhance the tourism sector. Further, Sukarara is also included in a strategic site planning 2011-2031 22 as one of cultural tourism development site offering woven product and traditional village. Another strategy is organizing annual event called "Sukarara begawe julu nyesek", which initiate by the village authority. ${ }^{23}$ This event invites weavers around the village to perform a mass weaving performance and exposure as a part of tourism attraction. Thus, the attempt is managed to place weaving as second main living source other than farming.

\section{F. Tenun Sasak in Indonesian Legal Discourse}

Currently, there is no particular regulation on the protection and the management of TCE. However, there are some partial arrangements in some laws and regulation in national and local scales as follows.

\section{The Copyright Law}

Indonesia has applied Copyright Law since decades ago or, precisely, since the enactment of Auterswet 1912 by the Government of Netherland Indies. However, the TCE protection was not automatically arranged in the IP system of Indonesia. In 1967, the first acknowledgement on the subject matter was blaze in Berne Convention. ${ }^{24}$ The convention arranged the ownership on "anonymous works". The state is obliged to form an institution under national law that competent to protect

\footnotetext{
21 Masnun, "Dekranasda Lombok Utara Launching Sentra Kerajinan", https://mataram.antaranews.com/berita/36199/dekranasda-lombok-utara-launching-sentra-kerajinan, downloaded on September 2018.

22 Sri Rahmi Yunianti, et.al, "Connectedness of Traditional Settlement Space in Sukarara Village Based on Nyensek and Begawe Value", Region Journal, Vol. 13, No. 1, 2018, p. 82.

23 Interview with Isnan Abdullah, loc.cit.

24 Cholis Roisah, "Protection of Traditional Cultural Expressions in Intellectual Property system", MMH, Vol. 43, No. 3, 2014, p. 374.
} 
published works that the creator is unknown. Such arrangement aims to represent the interest of the creator and to ensure that the creator gains benefits.

Based on the idea to contribute benefit to each creator as an appreciation on their work in the field of art, literary, and science, it is important to arrange the TCE's legal aspect through the Copyright Law. Therefore, the Law Number 28 of 2014 spares particular space for the arrangement of the TCE. According to Article 38, Paragraph (1), (2), (3), and (4), the copyright of TCEs are owned by the state and the state has an obligation to maintain, to guard, and to conserve it. Its utilization must notice the living and existed values within society.

The copyright protection of Tenun Sasak is focused on distinctive patterns of the fabric. According to Article 40 of the Copyright Law, the copyright is only given on the creation in the fields of art, literary, and science. Therefore, as a product that contains art value, Tenun's legal arrangement must be in accordance to the law. However, differ from "modern" arts creation, such as recorded music, architecture, and others, which has limited protection period, the protection period of the TCE is limitless. As long as it still existed, the legal protection is provided.

Based on the legal construction of the Copyrights Law, a tenun's pattern contains two derivative rights: economic and moral rights. Economic right refers to the right of creator to gain financial benefit from commercialization of the creation conducted by creator himself or other party permitted by the creator. Moral rights refer to the right of creator to put down his/her name on the creation (droit de paternite) and or the right to modify creation's title or content (droit au respect). ${ }^{25}$ In other words, the people of Sasak are entitled to commercialize Tenun as well as receiving certain percentage from other party (non-member of the society) who utilize the patterns. On the other hand, moral rights refer to right to claim reputation and acknowledgement of the creator. The implementation is in the form of prior informed consent. In this context, prior informed consent refers to social permission from the holder society on the utilization of weaving fabric pattern by other party.

\section{The Patent Law}

Similar to the Copyrights Law and other laws that are related to Intellectual Property, the Patent Law is also conceived as an implementation of TRIPs (Trade Related Aspects of Intellectual Property Rights) agreement in Indonesia. This agreement was initiated by industrial countries such the United States and the European Union countries desiring protection on their invention or product. In fact, this law often triggers controversies as it views industry and individual neglecting communal right protection contained in cultural products.

According to the Indonesian Patent Law Number 13 of 2016, invention refers to inventor's concept that is reflected in specific solution of technology, as either

25 Suyud Margono, “Legal Aspect of Intellectual Asset Commercialization”, Bandung: Nuansa Aulia, 2010, p. 15. 
product or process or advancement and development of a product or process. Therefore, Songket contains patent element since the fabric is a product of technology innovation of yarn spinning technique as well as application of certain substance to generate particular color. Therefore, technique and process of traditional weaving must be regulated properly under an Indonesian patent system.

To gain the patent right, an invention shall meet several conditions. According to the Patent Law, the conditions consist of novelty, inventive step, and industrial applicable. At a glance, the conditions seem to be moderate. However, they trigger controversies in the context of traditional fabric legal protection. The controversies are as follows. First, in the condition of novelty, examining novelty needs an invention prior art search method. It is conducted by tracking documents of patent office to ensure that the technology has never been registered before. This method also aims to ensure that an invention is genuinely new. In traditional weaving technology, both its technique and process are undocumented so that the invention is undated and anonymous. It is difficult to be patented. Second, the conditions cover inventive step for evidence. A technology must be tested through scientific examination. Tenun as a part of traditional knowledge do not recognize scientific system considering that the discovery is coincident, and it is developed hereditarily without modern science pattern. Tenun will not be able to fulfill the condition. Third, industrial applicable refers to detail disclosure of invention application in registration form, including description of industry to apply the invention. Traditional communities do not recognize such formality. The TCE application often involves certain ritual such as in the making Subahnale pattern, which is considered as a sacred pattern. Considering the sacredness, it must be started by prayer and is conducted in a place covered with net as a symbol of protection from evil. To address the controversies, the government amended the Patent Law by the Law Number 13 of 2016. This law is the first Indonesian Patent Law that arranges legal protection on the TCE. The arrangement is reflected in Article 26. The arrangements regulate that:

1) If the invention is related to genetic resources and/or traditional knowledge which are mentioned in attached description;

2) Information concerning genetic resources and/or traditional knowledge as mentioned in Paragraph (1) which is stated by a government institution; and

3) Benefit sharing and/or access to utilization of genetic resources and or traditional knowledge as mentioned in Paragraph (1) is applied according to Law and International Agreement in the field of genetic resources and traditional knowledge.

Nevertheless, the above arrangement gains critics especially from the indigenous community activists. Arranging the whole issues of traditional knowledge protection in a single article is seen ineffective to cover various interests of 
indigenous community on the subject matter. On the other hand, the government attempted to legalize their support to access and to benefit financially (for example: royalty) and non-financially (for example: involvement in research or community development program). Considering the importance of traditional knowledge for its holder community, therefore, the description of Article 26 of the Patent Law mentions "prior informed concern is obliged for non-member (of the community) users of traditional knowledge to prevent claims by other country." 26

\section{Trademark and Geographical Indications Law}

Based on the Law Number 20 of 2016 on Trademark and Geographical Indications, legal protection on Tenun can be embodied in geographical indications of origin and collective trademark registration. Article 1, Paragraph 4, of the Law arranges that collective trademark refer to trademark used on goods/services with similar characteristic on nature, general feature and quality of goods/services as well as it supervisory, which will be traded by a group of people or a legal entity simultaneously to distinguish with a similar good/services. Therefore, an indication of origin is original character of goods/services that is not directly related to nature. ${ }^{27}$ This description is in line with tenun, which characterized by distinctive pattern, production method, and product quality compared to other fabrics offered in market.

There are differences between collective trademark and indication of origin is in its registration. To generate right on collective trademark, registration is obliged and oppositely not on indication of origin. In other words, indication of origin can be done declaratively as a signature of product's origin.

Arrangement on collective trademark in this law aimed to support empowerment of micro, small, and medium enterprise and/or public service. The above statement is in line with the spirit of traditional economic enhancement, which requires adaptation between traditional values and modern management. Dutfield ${ }^{28}$ states that traditional economies can achieve success in the modern globalizing world. However, they need to conserve the best traditions while selecting the most useful resources, technologies, and institutions from outside and adapting them to meet their needs optimally.

In this context, trademark registration is a new introduced system for Sasak community and formal administration is not a familiar process in traditional community. Nevertheless, it can be an effective solution for the protection of their interest since registration will be able to prevent illegal duplication and copying as well enable enforcement on misappropriation.

On the other side, to gain collective trademark, Tenun Sasak must be registered and examined like regular trademark. Registration procedure related with the

\footnotetext{
See the description of Article 26 of the Law Number 13 of 2016 on Patent.

See the Article 63 of Law Number 20 of 2016 on Trademark and Geographical Indications

Graham Dutfield, op.cit, p. 4.
} 
applicant's or attorney identity and legality together with description of requested goods or services. On the other hand, examination consists of two steps namely administrative and substantive. Administrative examination covers registration form and fee completeness; and substantive examination covers former registered right to avoid double registration.

\section{Culture Advancement Law}

Legal protection on cultural aspect of Tenun Sasak can be viewed from the perspective of the Law Number 5 of 2017 on culture development. According to the law, the TCE is positioned as a capital to be used to build nation's future and civilization among the dynamics of world's development. Further, the law identified four aspects of culture advancement as follows. ${ }^{29}$

a. Protection consists of attempts to ensure culture sustainability, which is carried out through inventory, securing, maintaining, rescuing, and publication.

b. Development consists of attempts to vitalize cultural ecosystem as well as increase, enrich, and spreading cultures.

c. Utilization consists of culture advancement object empowering to strengthen ideology, politic, economy, social, culture, defense, and security to carry out national goals.

d. Nurturing consists of attempts to empower cultural human resources, cultural institutions, and cultural infrastructures in order to increase and broaden society's initiative and active role.

Thus, this law arranged weaving clothes as one of culture advancement object, which can be implemented by maintaining its noble values and wisdom; usage in daily life; maintaining it diversities; vitalizing and maintaining its ecosystem; Inheritance to the next generation. This arrangement is a reflection of the indigenous people on the TCE.

The Culture Development Law protects the TCE by inventory. Every object of cultural advancement, including Sasak TWC, is registered in integrated cultural database system, which covers the act of securing, maintaining, rescuing, publication, and development. Article 16 of this law regulates that inventory of TWC (as an object of culture advancement) consists of four stages: registration, documentation, stipulation, and data update. Securing the object of culture advancement is carried out by (1) consistently updating data in data system; (2) maintaining sustainable integrated culture; (3) passing the object to the next generation; and (4) initiating the object to be world's cultural heritage. ${ }^{30}$

29 Abdul Atsar, "Perlindungan Hukum Terhadap Pengetahuan dan Ekspresi Budaya Tradisional Indonesia untuk Meningkatkan Kesejahteraan Masyarakat Ditinjau dari Undang-undang Nomor 5 tahun 2017 tentang Pemajuan Kebudayaan", Jurnal Law Reform, Vol. 13, No. 2, 2017, pp. 293-294.

30 Article 22 of Law Number 5 of 2017 on Cultural Advancement. 
In the perspective of the indigenous people, TWC is a part of their identity as a community. Therefore, core issues on TWC protection is related to ownership and acknowledgement, as it is more urgent than the issues of economic exploitation and commercialization. Claiming or utilizing TWC illegally by outsider is considered as a contempt of community's pride.

\section{Arrangement in Local Scale}

It is evident that Tenun managed to contribute significantly for the life of the holder community both in the context of economic and cultural. To enhance and preserve its sustainability a locally made policy is urgently required. In the homeland of Sasak community, the Province of West Nusa Tenggara (NTB) protection forms provided for the subject matter are coaching and socialization.

The Office of Industry and Trade of the West Nusa Tenggara Province conducted training and socialization programs. During 2018 , the following activities has been conducted. ${ }^{31}$

a. Coloring training involved twenty participants from each regency across Lombok island;

b. Design improvement training was followed by weavers around Lombok. It was carried out together with the granting of tools donation funded by State Budget and Local Budget;

c. Product diversification training aimed to expand market target of the fabric. The weavers are expected to be able to produce "ready to wear" variants such as cloth, wallet, dress, suit, etc;

d. E-smart training targeted small and medium scale traders to introduce and familiarize them with online marketing which will enable them to connect directly with consumers;

e. Legal technic coaching was conducted in the form of introduction and debriefing of legal infrastructures in protecting TWF. Therefore, participants own technical ability in registering the Intellectual property right of their products.

In addition, socialization programs are carried out in various forms as follows. ${ }^{32}$

a. Promotion aimed to introduce tenun Sasak as a product to a wider scope by participating in local, national, and international exhibitions;

b. Inter-regional cooperation was conducted in order to expand distribution and marketing network.

It is important to note that the training programs are accidental and unsustainable since important requirements to reach marketing target or expected product

\footnotetext{
31 Evi Zubaidah, Head of Creative Industry Section of the Provincial Office of Industry and Trade, interviewed on September 10, 2018.

32 Ibid.
} 
diversification such as simultaneous financial assistant or continues mentoring for local weavers, are unavailable. On the other hand, development assistant is carried out partially by providing weaving tools such as thread and board. In term of socialization, the government needs to design effective program, which enables more participation from the society as well as small and medium scale industry actors. In line with the socialization, M. Isnan Abdullah ${ }^{33}$, the Head of Governance Bureau of the Sukarara Village, states that public's awareness on the protection of tenun are low since they do not realize that copying or imitating Tenun's pattern are an act of piracy and can be subjected as law infringement.

\section{G. Expected Protection Form on Economic and Cultural Elements of Tenun Sasak \\ 1. Database}

In this discussion, the term database refers to inventory or documentation of traditional knowledge and the TCE that are existed within the society. ${ }^{34}$ It can be a short-term solution to prevent misappropriation or illegal utilization by outsider (non-member of the community). Since 2004, inventory and documentation on Traditional Knowledge has been conducted all over Indonesia through IP centers or IP management units. The Ministry of Research and Technology initiated and managed to identify a number of traditional knowledge and the TCE in the field of traditional medicines, carving and sculpture, weaving, architecture, food and cuisine, plantation breeding wood varieties, and natural pesticides.

Inventory or identification can be used as an evident of Indonesian proprietorship on cultural creations. It enables the Indonesian Government to refuse outsiders' claims on the treasures. In addition, the database can be used as a comparison document on registration of identified IP and traditional knowledge and TCE. ${ }^{35}$ Moreover, the program can be considered as pioneer for further protection efforts of Traditional Knowledge and the TCEs.

According to the Ministry of Culture and Education, there are 2644 identified intangible cultural creations in Indonesia. However, only 77 of them have been officially recognized as world's heritage by the United Nation Educational, Scientific and Cultural Organization (UNESCO). They are, among others, Wayang, Keris, Angklung, Tari Saman, and Noken. ${ }^{36}$ Up to now, some Ministries organize separated inventory program. They are, among others, the Ministry of Culture and Tourism and the Ministry of Law and Human Rights via Directorate General of Intellectual Property. Separate data collection by different institutions leads to different result in both number and object variation. Therefore, standard procedure and inter-

\footnotetext{
Interview with M. Isnan Abdullah, loc.cit.

See Abdul Atsar, op.cit., p. 291.

Rohani, "Perlindungan Hukum terhadap Pengetahuan Tradisional Melalui Pengembangan Sui Generis Law", thesis in Faculty of Law, Lampung University, Lampung, 2015, p. 437.

36 Bayangsari Wedhatami and Budi Santoso, "Upaya Perlindungan Ekspresi Budaya Tradisional dengan Pembentukan Peraturan Daerah", https://media.neliti.com/media/publications/110672-ID-upayaperlindungan-ekspresi-budaya-tradi.pdf downloaded on January 2019.
} 
institutions coordination are required to generate a well-organized and integrated data.

Ideally, the database does not only contain inventory results but is also able to map each regions' potential together with development optimization efforts by utilization of existed Traditional Knowledge and TCEs. In institutional level, coordination is required to construct integrated data system that enables the Government to formulate cross-cutting policies.

\section{Regional Regulation}

Currently, the Government of West Nusa Tenggara Province has no particular regulation on Tenun Sasak, even though it has become an essential part of the local community both economically and culturally. The neighbor provinces have gone further. For instance, the Government of Bali has finalized the draft of regional regulation on the protection of traditional fabric.

One of the reasons of the urgency of regional regulation is the increasing interest on traditional handmade fabric led to the vulnerability of copyright violation such as pattern imitating. According to the data provided by Office of Industry and Trade of the Province, in 2008, Endek (Bali's traditional fabric) is local flagship product with significant export potential. The claim evident by the amount of exported fabric in 2014, which was 52.052 .053 sheets, generated approximately Rp1.250.137,87. ${ }^{37}$ Similar with Tenun Sasak, the promising selling value lead to a high number of imitating activities as fake printed products can easily be found at local market or shopping center. The fake products offer cheaper price than the original.

Essentially, the above regional regulation draft should provide copyright protection form for the subject matter and, therefore, put copyright law as its major legal basis. There are two main basic understandings as follows.

a. The protection principles cover preventive and repressive efforts to anticipate cultural damage or extinction in terms of idea, behavior, and creation, including dignity and pride, caused by humans' action or natural processes.

b. Traditional weaving fabrics refer to fabrics that are produced from naturalbased materials, processed with non-mechanical tools, and existed as local cultural creation.

Based on the description, there are character similarities between Tenun Sasak and Bali's Traditional fabric. Therefore, the protection scheme embodied in Bali is a congruent comparison material to form regional regulation in Lombok.

\section{H. Conclusion}

Traditional weaving fabrics are part of identity of the Sasak people who inhabit about eighty percent area of Lombok Island. Philosophically, Tenun Sasak is viewed

37 See, Draft of Academic Script of Bali Local Law on Protection of Traditional Fabric, p. 4. 
as cover or mawastre of users' body. In cultural and economic dimensions, it is a cultural heritage passed inter-generation. It reflects the people's socio-cultural character as well as a source of livelihood. In Indonesian legal discourse, the arrangement on Tenun Sasak can be found in several laws and regulations. They are, among others, (1) regulations in the field of Intellectual Property; (2) regulations outside the field of Intellectual Property; (3) regional regulations. Tenun Sasak as a part of TCE requires a more appropriate and holistic arrangement to protect its aspects and secured the interest of its holder society. Expected arrangement is divided into three forms, namely (1) database formation; (2) Sui generis law; (3) regional regulation that specifically arranges Tenun Sasak.

\section{References}

\section{Books}

Agus Sardjono, Hak Kekayaan Intelektual dan Pengetahuan Tradisional, Alumni, Bandung, 2006.

A. Mangunhardjana, Isme Isme dalam Etika dari A-Z, Kanisius, Jogjakarta, 1997.

Badan Penelitian dan Pengembangan HAM KEMENKUMHAM RI, Perlindungan Kekayaan Intelektual atas Pengetahuan Tradisional dan Ekspresi Budaya Tradisional Masyarakat Adat, Alumni, Bandung, 2013.

OK Saidin, Aspek Hukum Hak kekayaan Intelektual (Intellectual Property Rights), Raja Grafindo Persada, Jakarta, 2006.

Satjipto Rahardjo, Sisi Lain Orang Indonesia Jawa, Kompas, Jakarta, 2003.

Suyud Margono, Legal Aspect of Intellectual Asset Commercialization, Nuansa Aulia, Bandung, 2010.

\section{Other Documents}

Abdul Atsar, "Legal Protection on Indonesia's Traditional Knowledge and Traditional Cultural Expressions Perlindungan Hukum terhadap Pengetahuan dan Ekspresi Budaya Tradisional Indonesia untuk Meningkatkan Kesejahteraan Masyarakat Ditinjau dari Undang-Undang Nomor 5 Tahun 2017 tentang Pemajuan Kebudayaan", Jurnal Law Reform, Vol. 13, No. 2, 2017.

Afifah Kusumadara, "Pemeliharaan dan Pelestarian Pengetahuan Tradisional dan

Ekspresi Budaya Tradisional: Perlindungan Hak Kekayaan Intelektual dan Non Hak Kekayaan Intelektual Indonesia", Jurnal Hukum, Vol. 18, No. 1, 2011.

Antariksa, Basuki, "Opportunity and Challenge on the Protection of Traditional Knowledge and Traditional Cultural Expressions", presented paper in Confinement of Intangible Heritage Program, Ministry of Culture and Tourism, Jakarta, 2011.

Antons, Christoph, "Asian Borderlands and the legal protection of Traditional Knowledge and Traditional Cultural Expressions", Cambridge Law Journal, Vol. 47, Issue 4, 2013. 
Bayangsari Wedhatami and Budi Santoso, "Upaya perlindungan Ekspresi Budaya Tradisional dengan Pembentukan Peraturan Daerah", https://media.neliti.com/media/publications/110672-ID-upaya-perlindunganekspresi-budaya-tradi.pdf.

Cholis Roisah, "Perlindungan Ekspresi Budaya Tradisional dalam Sistem Hukum Kekayaan Intelektual”, MMH, Vol. 43, No. 3, 2014.

, "Kebijakan Hukum "Transferability" terhadap Hak Kekayaan Intelektual Indonesia", Jurnal Law Reform, Vol. 11, No. 2, 2015.

Dutfield, Graham, "Harnessing Traditional Knowledge and Genetic Resources for Local Development and Trade, Draft paper Presented at the International Seminar on Intellectual Property and Development", 2005.

Dwi Martini (et.al), "Perlindungan Hukum terhadap Pengetahuan Obat Tradisional dalam Rezim Hak Kekayaan Intelektual (HKI) Indonesia (Studi Pada Masyarakat Tradisional Sasak)", Jurnal Hukum dan Peradilan, Vol. 6, No. 1, 2017.

Hastira Soekardi, "Kenali 3 Jenis Kain Tradisional Suku Sasak Lombok", kompasiana.com/hastira/kenali-3-jenis-kain-tradisional-suku-sasak lombok_5772d359af7e61870d98500b, downloaded on May 28, 2017.

Maria Nona Elvida, "Pembuatan Kain Tenun Ikat Maumere di Desa Wololora, Kecamatan Lela, Kabupaten Sikka Propinsi Nusa Tenggara Timur, Jurnal Holistik, Tahun VIII, No. 16, 2015.

Masnun, "Dekranasda Lombok Utara Launching Sentra Kerajinan", https://mataram.antaranews.com/berita/36199/dekranasda-lombok-utaralaunching-sentra-kerajinan, downloaded on September 2018.

Janner Raja Simamarta, Ulos Batak: "Sejarah, Makna dan Jenisnya", Simarmata.or.id/2016/04/ulos-batak-sejarah-makna-dan-jenisnya/", downloaded on May 28, 2017.

Rohani, "Perlindungan Hukum terhadap Pengetahuan Tradisional Melalui Pengembangan Sui Generis Law", thesis in Faculty of Law Lampung University, Lampung, 2015.

Sarah S. Kuahaty, "Kain Tenun sebagai Pengetahuan Tradisional Masyarakat Hukum Adat Maluku", http://fhukum.unpatti.ac.id/.../272-kain-tenun-, downloaded on December 10, 2018.

Simona Bustani, "Urgensi Pengaturan Ekspresi Budaya (Folklore) Masyarakat Adat", Jurnal Hukum Prioris, Vol. 2, No. 4, 2010.

Sri Rahmi Yunianti (et.al), "Connectedness of Traditional Settlement Space in Sukarara Village Based on Nyensek and Begawe Value", Region Journal, Vol. 13, No. 1, 2018.

Yoga Mahardhita, Ahmad Yakub Sukro, "Perlindungan Hukum Hak Kekayaan Intelektual Melalui Mekanisme Cross Border Measures", Jurnal QISTIE, Vol. 11, No. 1, 2018. 
Zainul Daulay, "Konsep Perlindungan Hukum terhadap Pengetahuan Tradisional Masyarakat Asli tentang Obat di Indonesia", Jurnal Media Hukum, Vol. 19, No. 2, 2012.

\section{Legal Documents}

The 1945 Constitution of the Republic of Indonesia [Undang-Undang Dasar Negara Republik Indonesia Tahun 1945].

Law Number 28 of 2014 on Copyright [Undang-Undang Nomor 28 Tahun 2014 tentang Hak Cipta].

Law Number 13 of 2016 on Patent [Undang-Undang Nomor 13 Tahun 2016 tentang Paten].

Law Number 20 of 2016 on Trademark and Geographical Indication [UndangUndang Nomor 20 Tahun 2016 tentang Merek dan Indikasi Geografis].

Law Number 5 of 2017 on Cultural Enhancement [Undang-Undang Nomor 5 Tahun 2017 tentang Pemajuan Kebudayaan]. 